\title{
Illustration and childhood imagination: narrative paths through the image in books for children
}

João Manuel Caetano jcaet@hotmail.com

Rosa Maria Oliveira rosaoliv@ua.pt

Universidade de Aveiro, Departamento de Comunicação e Arte, Portugal

Reference

Resumo

Palavras-clave
Caetano, João Manuel; Oliveira, Rosa Maria; (2012) "Illustration and childhood imagination: narrative paths through the image in books for children", p. 103-107. In: Barbosa, Helena; Quental, Joana [Eds]. Proceedings of the 2nd International Conference of Art, Illustration and Visual Culture in Infant and Primary Education. São Paulo: Blucher, 2015. ISSN 2318-695X, ISBN: 978-989-98185-0-7 DOI 10.5151/edupro-aivcipe-21

The aim of this study is to highlight the importance of illustration published in Portugal between the 40 s and 70 s of last century, intended for children and youth. Having started with story books, illustration has always been present in other areas of publishing. Comics, scrapbooks, didactic and entertaining games, children's records and collections of stickers are some of the areas where illustration has left its marks. In this route, illustration not only reinforced its status as an autonomous art form, but also contributed to the creation of an affective and emotional space that is still preserved in our collective memory.

graphics, illustration, comics, game, visual memory, affective memory

1 Introduction

The expansion of publishing mainly observed since the second half of the 2oth century, reflected a growing attention given to the education of the children and provided a unique opportunity for illustrators to venture in very diverse creative environments, then redefining their own aesthetic models and personal styles.

We know that the history of the Portuguese illustration for the younger began to be written at the end of the 19th century and is closely linked to the book?

But in the first few decades of the zoth century comic strips helped the overall development of illustration to integrate new concepts such as sequencing and movement, notions that were largely inherited from the photography and film.

At the end of the first half of the zoth century, comic magazines, also known in the "the Portuguese" version as stories in little squares², had already conquered their own space. Criticized by some and loved by many, affordable in price but often of poor quality graphics, comic magazines were responsible for the creation of new narrative structures that were used differently in various areas of publishing: illustrated tales, assembling kits, cut books (and clippings), coloring books, educational games, stickers, album covers, etc. These were areas in which illustration even tried its luck, in a period under the censorship of the Estado Novo (New State's regime) which moved through the Reading Committees, appeared to be particularly inhibiting of the creative impetus that seethed in publications aimed at children and young people.

In fact it was in the children's book that many Portuguese illustrators began their career. Newspapers aimed at children were usually designed by foreign authors, regarding both the pictures and the texts. The first entirely Portuguese experience was ABCzinho (The Little ABC) (19211932), a biweekly publication "responsible for several innovations, especially for having been the first magazine for children, worthy of the name, to achieve great popularity》 (1987, p. 100). Other comic strips publications followed such as O Senhor Doutor (The Doctor) (1933-1957), O Papagaio (The Parrot) (1935-1949), O Cavaleiro Andante (The Knight Errant) (1952-1962). The connection between comics and illustration Emmerico Nunes, Eduardo Malta, Rocha Vieira, Carlos Botelho - became a reality, contributing to the emergence of new publishing initiatives. 2 The term is likely derived from the Brazilian terminology Histórias aos Quadrinhos. 
2nd International Conference Art, Illustration and Visual Culture in Infant and Primary Education $2^{\circ}$ Congreso Internacional

Arte, llustración y Cultura Visual en Educación Infantil y Primaria
Arte, llustração e Cultura Visual

na Educação Infantil e Primária

\section{Illustration's visual mobility: from the tale to the game}

Figure 1. Sequence of illustrations by author unknown, pp. 3-6, not dated

Figure 2. Text and illustrations by Gabriel Ferrão for História Maravilhosa do

Pastorinho João (The Wonderful Story of Little Shepherd John), Colecção Sarapico-Mafarrico, $n^{\circ} 4$, Editorial Infantil Majora, not dated
According to António Lopes Ribeiro, the invention of photography and film marked the beginning of the "graphics time" that, in its opinion, would follow the "literary time" initiated by the invent of Gutenberg. The graphics time is especially the image time - fixed in the frame, moving on the screen or printed on paper -, a time of great artistic and expressive permeability.

In the illustrated editions for children, this was also the time of the moving image - illustration, cartoon, comic strip - and of the "mobile" image - pop-ups, puzzles, dominoes, card games.

In A Pastorinha (The Little Shepherdess), an eight-page short story published by APR (in the 6os?), we find a very simple but effective scheme in which the sequence and the movement are organized very much like the comic strip (Fig. 1)
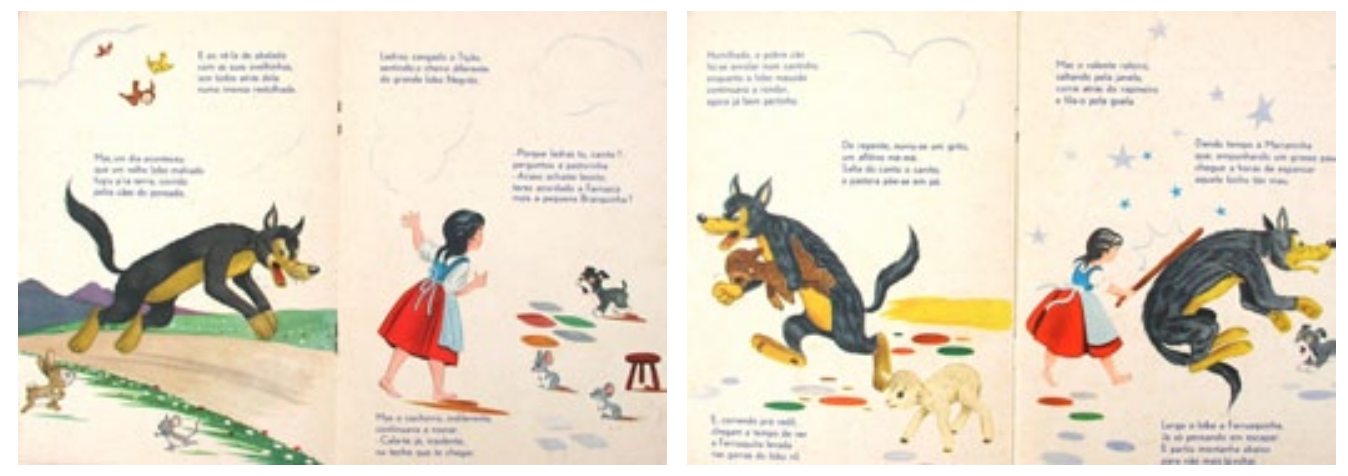

In Colecção Sarapico-Mafarrico the scheme is different, more according to the normal rules of illustration. Setting at least one illustration per page, side by side with the text (fig. 2), the author seeks to establish a permanent relationship and almost simultaneous between what is being "read" and what is being "seen".

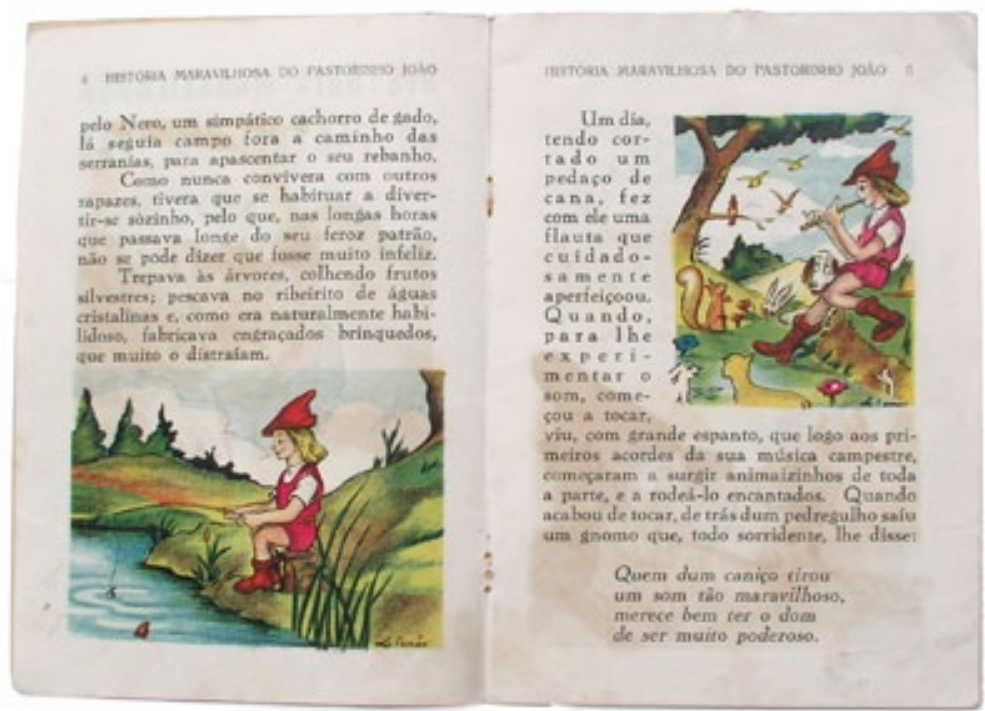

In this case, one can guess even a certain parallelism with the animated film, mainly because the boy's figure suggests having been "modelled" from one scene to another - in one he is fishing, in the other he is playing the flute -; while keeping the same profile in the figure, colors and sizes also very similar, the substantial change seems to have happened only in the landscape that "slides" beneath the character. Another case of a possible "rhythmic reading" between text and image are the three tales - of "Carochinha" (The Little Beetle), "Little Red Riding Hood" 
$2^{\text {nd }}$ International Conference

Art, Illustration and Visual Culture in Infant and Primary Education
${ }^{\circ}$ Congreso Internacional

Arte, Ilustración y Cultura Visua! en Educación Infantil y Primaria
${ }^{\circ}$ Congresso Internacional

de Arte, Ilustração e Cultura Visual

na Educação Infantil e Primária
Figure 3. Vou-Ihes contar uma história (I will tell you a story), illustrated leaflet, not dated
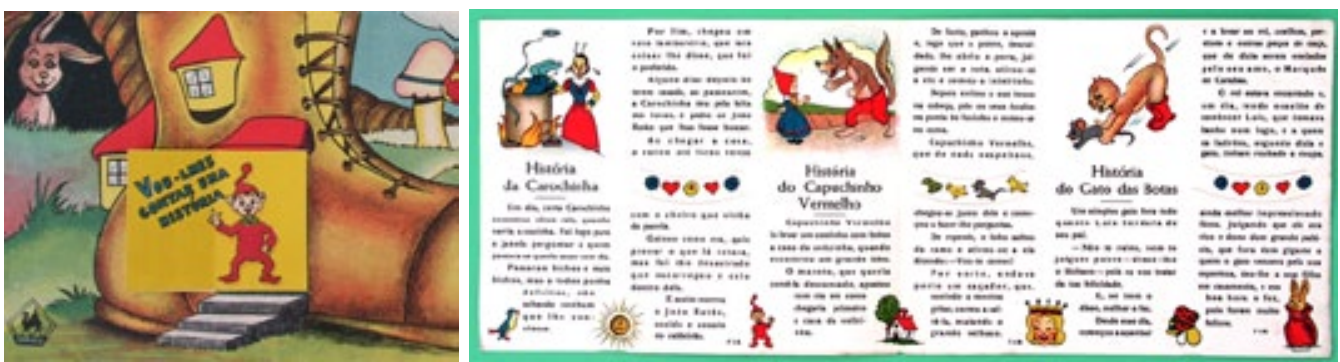

and "Puss in Boots" - that make up the leaflet "I will tell you a story"3. (fig.3) Note the very small figures that "run" below the text highlighting through repetition, the animated character of the publication and the reading cadence.

It was also common to find different editions of the same work. Such was the case of the transposition of the titles of the "Silver Series", in carton edition, for the "Tales of the Thousand and One Nights Collection ", a smaller and more economic paperback edition, both illustrated by César Abbott and published by Majora.

We know that the choice of the book size is not only an editorial issue and a commercial attitude; it is also a way to interfere in the sphere of affections and desires. A little book will always be very "cute", irrespective of the material that has been used in its making. Some of them were indeed very tiny - Colecção Tonecas $(7,5 \times 6 \mathrm{~cm})(\mathrm{APR})$ or Coleç̧ão Formiguinha $(9,7 \times 7,3 \mathrm{~cm})$ (Majora) - but freely coexisted with other much larger, as was the case of Colecção Gigante $(32 \times 15 \mathrm{~cm}$ ) (Romano Torres), which would produce at least four titles.
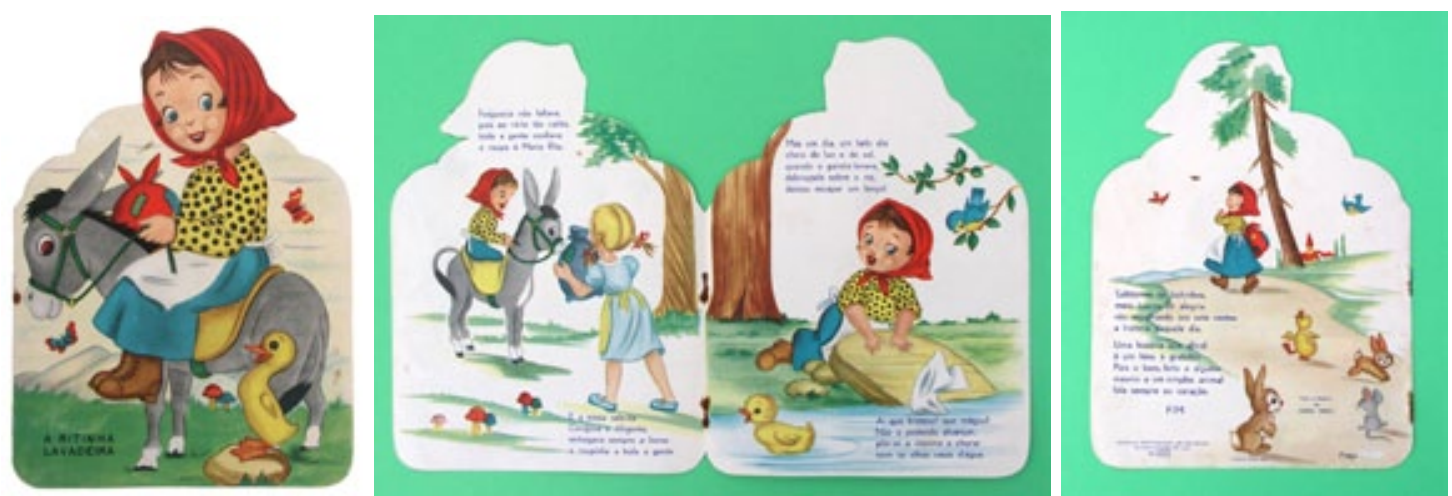

Figure 4. A Ritinha Lavadeira (Little Rita Laundress), Portuguese Magazine Agency, illustrator unknown, not dated Joanita Corre Mundo (Little Joana Run the World), illustrations by Gabriel Ferrão, Editorial Infantil Majora, not dated
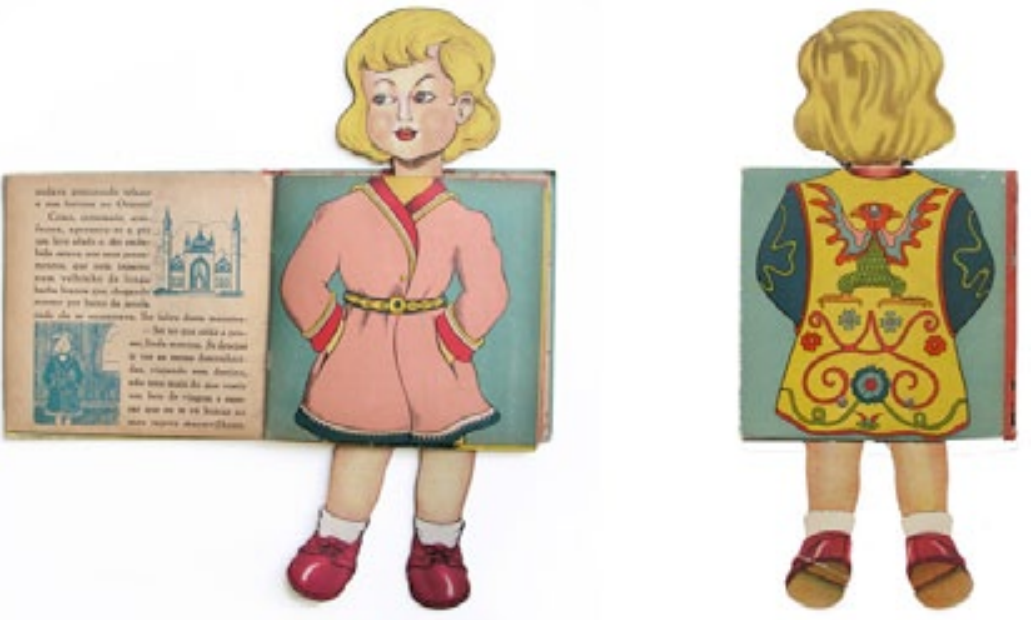
$2^{\text {nd }}$ International Conference Art. Illustration and Visual Culture in Infant and Primary Education $2^{\circ}$ Congreso Internacional

Arte, Ilustración y Cultura Visual en Educación Infantil y Primaria iresso Internacional

e Arte, llustracãa e Cultura Visual

na Educação Infantil e Primária
Figure 5. Branca de Neve e os Sete Anões (Snow White and the Seven Dwarfs), book with clippings and respective game, illustrations by César Abbott, Majora, not dated
In addition to the sizes, there was still the issue of formats and materials used, evident in the diversity of existing typologies at the time: cut books or with clippings on the inside (fixed or articulated), cloth books, coloring books, sticker books and many others. Whether they were simple or complex technical mechanisms, interaction with the object-book was fundamental. We have found in many of these works a certain degree of commitment between the reading experience and the image experience (Fig. 4); the same happened, moreover, with the discs for children, another kind much in vogue at the time and whose drawings of the covers and interior often resembled the structure of a book.

The toy book opened the way for the appearance of the illustrated game in its many variants: lottos, puzzles, cards, dominoes, board games, etc. Traditional stories were still the source of inspiration. Certainly motivated by the impact of Walt Disney film, Snow White and the Seven Dwarfs simultaneously became book with clippings and table game. (Fig. 5) Given the similarity between these two formats, both in their narrative structure and in their chromatic component, it is very likely that César Abbott had developed both projects together and at the same time.
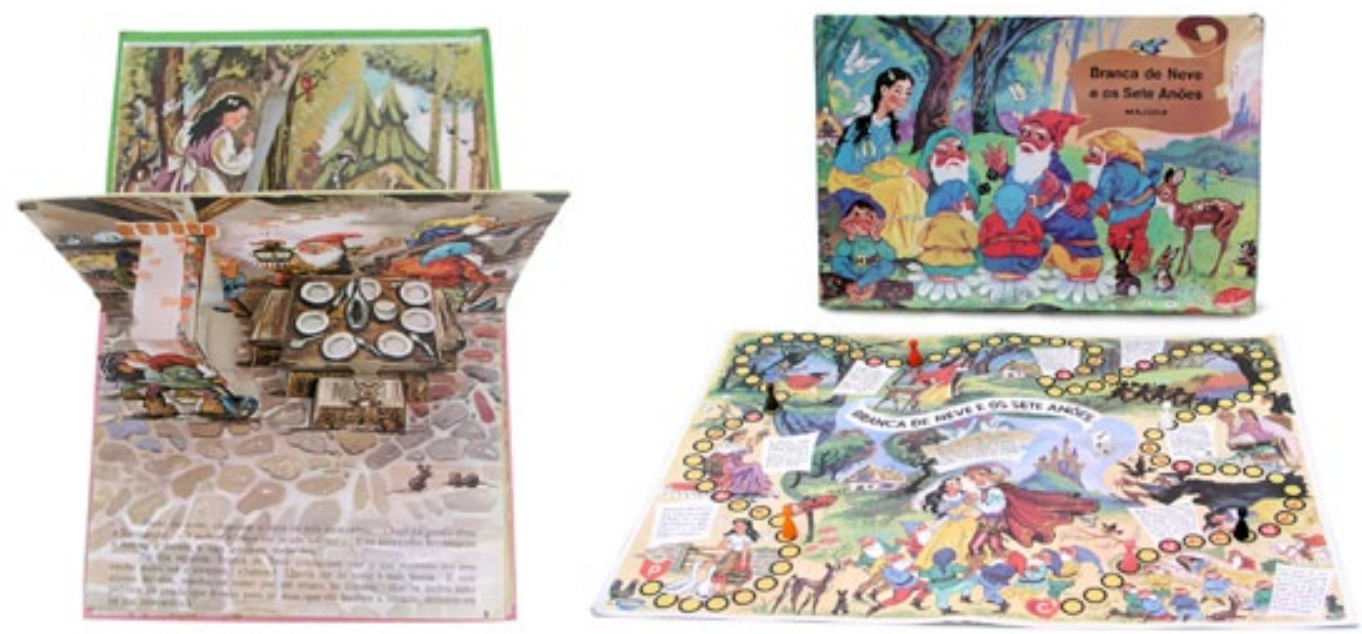

In the mid-twentieth century editorial diversity in the field of works for children in Portugal reached a level of development and a quality truly appreciable.

Progressing almost against cycle with what was happening in youth literature - this much more dependent on imported editions, or in national terms, limited to certain themes by government enforcement - the children's sector knew a vitality of its own, multiplying the number of small magazines, games and other educational and entertainment objects based on the book. A lode that national publishers and illustrators used the best way, giving form to a project that sometimes seemed to be driven by a desire almost childish, but maybe because of that, was able to perpetuate itself in time and memory.

This experience, which took place more than half a century ago, represents today the living testimony of one of the most splendid eras of juvenile publication in Portugal.

\section{Bibliography}

BLOCKEEL, F. (2001). Literatura Juvenil Portuguesa Contemporânea - Identidade e Alteridade, Collection "Universitária", n 92, 1ª edição, Editorial Caminho, Lisboa.

BRAVO-VILLASANTE, C. (1977). História da Literatura Infantil Universal - II, Editorial Vega, Lisboa.

FERREIRA, A. J. (1998) O Jornal Infantil Português Ilustrado - 1874/1975, Poly-copied text in author's edition, $2^{a}$ edição, Lisboa. 
$2^{\text {nd }}$ International Conference Art, lllustration and Visual Culture in Infant and Primary Education $2^{\circ}$ Congreso Internacional

Arte, Ilustración y Cultura Visual en Educación Infantil y Primaria $2^{\circ}$ Congresso Internacional

de Arte, Ilustração e Cultura Visual na Educação Infantil e Primária

FERRO, J. P. (1987) História da Banda Desenhada Infantil Portuguesa - das origens até ao ABCzinho, Collection Dimensões, Editorial Presença, Lisboa.

GERVEREAU, L. (2007). Ver, compreender, analisar as imagens, Colecção Arte \& Comunicação, Edições 70, Lda., Lisboa.

MASSIRONI, M. (1982). Ver pelo desenho - aspectos técnicos, cognitivos, comunicativos, Edições 70, Lisboa.

RIBEIRO, A. L. (1978). Aspectos do nosso tempo - Belas-Artes \& Malas-Artes -Edições A Rua.

VILELA, A. (1992). O Livro e suas técnicas, edition sponsored by Editora Correio do Minho and Parque de Exposições de Braga. 